librarian at the D. H. Hill Library, North Carolina State University, Raleigh, on December 31. She had served as cataloger for 30 years.

Russell M. SMith, manuscript historian and specialist in microfilm publications in the Manuscript Division of the Library of Congress, retired in November after more than 24 years of Federal service.

DEATHS

Marion CobB, lecturer and librarian of the laboratory collection at the Graduate School of Library and Information Science, University of California, Los Angeles, died suddenly on December 25 while visiting his family for the holidays. He had served the UCLA library school since 1969 and was a noted expert on AfroAmerican bibliography.

Peggy Fackre, librarian of the Engineering, Mathematics and Science Library at the University of Waterloo, Ontario, died in December.

Mollie Thomson, deputy librarian of Macquarie University, North Ryde, New South Wales, Australia, died October 21 after a long illness. Thomson was New York Liaison Officer of the National Library of Australia in 1960-63 and obtained an MLS at Columbia University at that time.

口

\section{Some Things} You Can

\section{Count On.....}

- Inadequate book budget

- Priority orders

- Books wanted "Yesterday"

- THE BOOK HOUSE

Call Toll Free 800 - 248 - 1146

Michigan Customers Call Collect

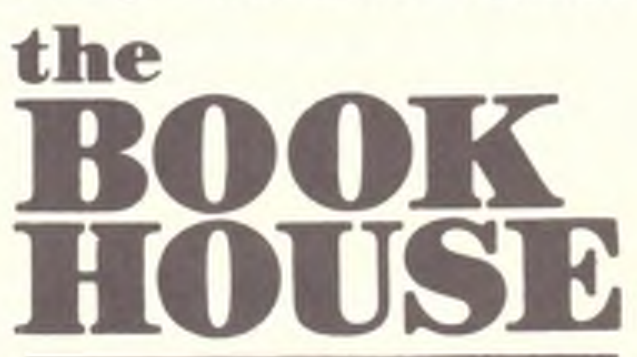

JOBBERS SERVING LIBRARIES WITH ANY BOOK IN PRINT SINCE 1962 208 WEST CHICAGO STREET JONESVILLE, MICHIGAN 49250

\title{
Publications
}

\section{NOTICES}

- Annual Salary Survey 1979-80, compiled by Gordon Fretwell (32 pages, December 1980), has been published by the Association of Research Libraries. It provides information on median and beginning professional salaries for filled or temporarily vacant positions in all ARL libraries at the beginning of fiscal year 1980-81. It is available to ARL members for $\$ 3$ and to others for $\$ 5$, prepayment required, from ARL, 1527 New Hampshire Ave., N.W., Washington, DC 20036.

- ARL Statistics 1979-80, compiled by Carol A. Mandel and Mary P. Johnson (66 pages, January 1981), has been issued by the Association of Research Libraries as part of its annual statistical series analyzing the collections, staffing levels, expenditures, and interlibrary loan volume of its member libraries in the United States and Canada. It is available to ARL members for $\$ 3$ and to others for $\$ 5$, prepayment required, from ARL, 1527 New Hampshire Ave., N.W., Washington, DC 20036.

- Biblioteca De Re Metallica: The Herbert Clark Hoover Collection of Mining and Metallurgy, edited and annotated by David Kuhner and
Tania Rizzo (239 pages, 1980), has been published by the Libraries of the Claremont Colleges, Claremont, California. Cyril Stanley Smith, Massachusetts Institute of Technology metallurgist and historian, wrote a scholarly introduction for the octavo volume. The work is a catalogue of the reference library on mining and metallurgy which former President Herbert Hoover and his wife, Lou Henry Hoover, assembled in London during their early careers. It may be purchased for \$125 from the Honnold Library, Claremont Colleges, Claremont, CA 91711.

- Earth-Sheltered Housing: An Annotated Bibliography and Directory, by Pauline A. Keehn (61 pages, January 1981), has been published by the Council of Planning Librarians as number 43 in the CPL Bibliography series. It includes over 200 titles from both technical and popular literature. Keehn is associate librarian in the Catalog Department at the University of California at Davis. It may be obtained for $\$ 11$ from the Council of Planning Librarians, 1313 E. 60th St., Chicago, IL 60637.

- A Guide to the Nikic Collection for the Study of Balkan Peoples, by Alexandra Filippenko (421 pages, 1980 ), is an index to a formerly 
private library acquired from Belgrade, Yugoslavia, by the University of California, Santa Barbara. The collection contains approximately 15,000 volumes represented by 6,229 titles including books, periodicals, pamphlets, and festschriften. It may be obtained for $\$ 12.50$ from the Librarian's Office, University of California, Santa Barbara, CA 93106.

- LEX: A Bibliography of Legal Resources for the Layman (48 pages, 1980), has compiled by METRO, the New York Metropolitan Reference and Research Library Agency. The guide is available for $\$ 10$ ( $\$ 15$ if not prepaid) from METRO, 33 West 42nd St., New York, NY 10036.

- Serial Cataloging: A Comparison of AACR 1 and 2, by Judith Cannan (73 pages, 1980), has been published by METRO, the New York Metropolitan Reference and Research Library Agency, as number 28 in its Miscellaneous Publications series. It may be ordered for $\$ 12.50$ from METRO, 33 West 42nd St., New York, NY 10036.

\section{AUDIOVISUAL NOTICE}

- Poetry Tapes at Stony Brook, compiled by Joseph A. Lipari (80 pages, 1980), provides annotations on the video and audio tapes of 62 poets made while they read and commented on their own works during visits to the State University of New York at Stony Brook. Copies of the catalog, as well as information on loan availability of the nearly 200 tapes in the collection, may be obtained from Audio Visual Services, Frank Melville Jr. Memorial Library, State University of New York, Stony Brook, NY 11794.

\section{RECEIVED}

(Selected items will be reviewed in future issues of College \& Research Libraries.)

- Richard Boss and Deanna Marcum report on "The Library Catalog: COM and On-Line Options" in Library Technology Reports 16:5 (September-October 1980). Their report concentrates on COM and online catalog alternatives which can be ordered essentially "off the shelf" from one of the vendors.

- No. 32 in Greenwood Press' Contributions in Librarianship and Information Science series is Defending Intellectual Freedom: The Library and the Censor (1980, \$22.95), a collection of Eli Oboler's essays on the defense and promulgation of freedom of thought and the battle against censorship.

- Pierian Press has published Library Research Guide to History: Illustrated Search Strategy and Sources by Elizabeth Frick (1980, $\$ 9.95, \$ 5.95 \mathrm{pa})$. Other titles in the Library Research Guides series examine religion and theology, biology, education, and sociology.
- A methodology for the analyses of library networks is developed by William B. and Sandra H. Rouse in Management of Library Networks: Policy Analysis, Implementation and Control (John Wiley \& Son, 1980). The authors inlcude a step-by-step procedure for applying their methodology.

- The International Guide to Library, Archival, and Information Science Associations by Josephine R. Fang and Alice H. Songe is now available from Bowker $(1980, \$ 32.50)$. This is the second edition of International Guide and it includes 59 international and 450 national associations from 178 countries.

- Nancy B. Olson, winner of the 1980 Esther J. Piercy Award, has written Cataloging of Audiovisual Materials: A Manual Based on AACR2 (Minnesota Scholarly Press, 1980, \$17.50). Ms. Olson participated in the development of standards and guidelines for cataloging AV materials under AACR2 Rules.

- On-Line Public Access to Library Bibliographic Data-Bases: Developments, Issues and Priorities. Final Report to the Council on Library Resources (OCLC, Inc. and RLG, Inc., 1980) reports on several activities undertaken to assess the critical issues and problems in designing and developing library bibliographic retrieval systems for direct patron use.

- A new edition of the filing rules is now available from the Library of Congress. Library of Congress Filing Rules (LC, 1980) supersedes the 1956 edition of Filing Rules for the Dictionary Catalog of the Library of Congress, as well as the 1971 provisional version, Filing Arrangement in the Library of Congress.

- The National Library of Canada has introduced the new microfiche version of Canada's national bibliography, Canadiana. Canadiana (Microfiche) is a COM version (42:1 reduction) published eleven times a year. A subscription to Canadiana (Microfiche), including annual cumulation, is $\$ 80$ in Canada, $\$ 96$ in U.S., payable in advance. Address enquiries to: Canadiana Editorial Division, Cataloguing Branch, National Library of Canada, 395 Wellington St., Ottawa, Ontario KIA 0N4.

- Shelf Classification Research: Past, Present-Future? by Richard J. Hyman is the topic of the latèst Occasional Papers (no. 146, November 1980). This 60-page publication is available for $\$ 2$ from the Publications Office, Graduate School of Library Science, 249 Armory Building, Champaign, Illinois 61820 .

- Volume 10 of Advances in Librarianship (Academic Press, 1980, \$23) includes chapters on AACR2, academic library management studies, bibliographic instruction, library materials budgeting in the private university library, individual decision theory, and library education in third world nations. Volume 10 was edited by Michael H. Harris, University of Kentucky. 
- OCLC: Its Governance, Function, Financing, and Technology by Albert F. Maruskin (Marcel Dekker, 1980, \$22.75) analyzes the growth and development of OCLC, Inc., utilizing a variety of primary source materials. OCLC is volume 32 in the Books in Library and Information Science series.

- The second edition of Library Management by Robert D. Stueart and John Taylor Eastlick (Libraries Unlimited, 1980, \$22.50 U.S., \$27 elsewhere; $\$ 14.50$ pa. U.S., $\$ 17.50$ elsewhere) discusses the effects of such factors as increased staff participation in the decision-making process, unionization and collective bargaining, the historical background and development of library management, networking, and women and minorities as managers.

- Introduction to Cataloging and Classification, Fifth Edition by Mildred Harlow Downing is now available from McFarland \& Company (1981, \$14.95). Introduction to Cataloging, re- vised and enlarged in accordance with AACR2 and the 19th edition of the Dewey Decimal Classification, is directed at students beginning the study of cataloging and classification.

- A guide to the present British copyright law as it affects practicing librarians, and a worldwide survey of recent developments and controversies is the topic of Copyright for Librarians by L. J. Taylor (Tamarisk Books, 1980, £7.50).

- Planning for Computing in Higher Education (Westriew Press, 1980, \$25), edited by James C. Emery, addresses planning for the use of computing and information resources on college and university campuses. Considered are computer applications in the areas of instruction, research, and administration, and an analysis of these from the viewpoints of faculty, administrators, and computer center directors. Also discussed is the use of a facilities management firm as an alternative for providing computer services.

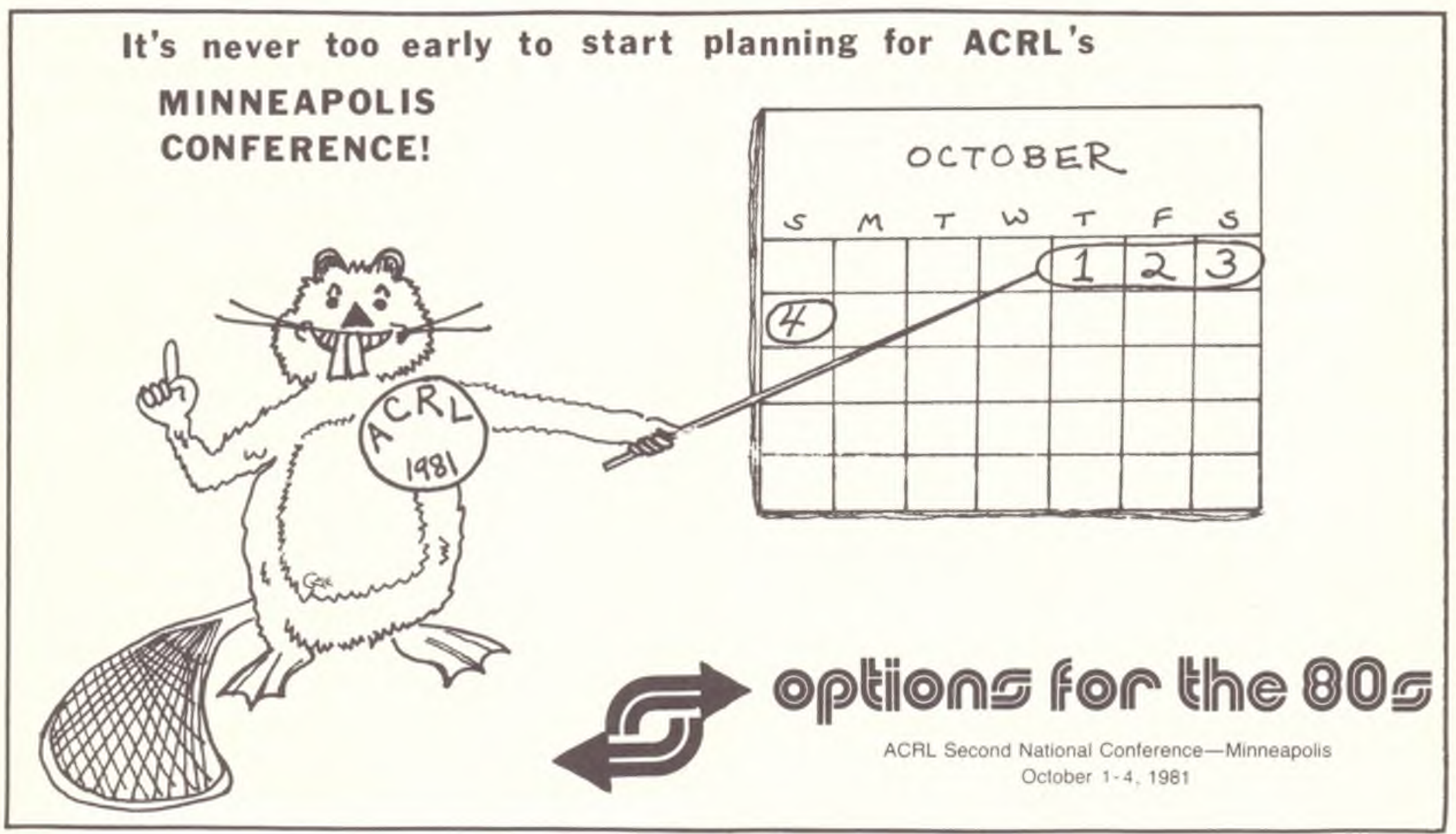

\section{March}

22-24-Publishing: Fourth American Book Publishing Institute, Emory University, Atlanta, Georgia. The institute will focus on current developments in publishing as they impact on libraries, bookstores, and authors. Fee: \$105.

\section{Calendar}

Contact: Division of Librarianship, Emory University, Atlanta, GA.30322; (404) 329-6840.

27-29-Ephemera: "Collecting, Collectors and Collectibles," Second Annual Conference and Fair of the Ephemera Society of America, Rve Town Hilton, Rye, New York. Contact: William Frost Mobley, P.O. Box 333, Wilbraham, 